\title{
Revisiting External Pecking Order Hypothesis: Evidence from Sri Lankan Companies Capital Structure
}

\author{
Dewundara Liyanage Prasath Manjula Rathnasingha, Chanthun P. Heiyanthuduwa \\ Department of Finance, University of Colombo, Colombo, Sri Lanka \\ Email: prasath@dfn.cmb.ac.lk, chathunheiyanthuduwa@yahoo.com
}

How to cite this paper: Rathnasingha, D. L. P. M., \& Heiyanthuduwa, C. P. (2019). Revisiting External Pecking Order Hypothesis: Evidence from Sri Lankan Companies Capital Structure. Journal of Financial Risk Management, 8, 200-223. https://doi.org/10.4236/jfrm.2019.84014

Received: September 16, 2019 Accepted: November 17, 2019 Published: November 20, 2019

Copyright $\odot 2019$ by author(s) and Scientific Research Publishing Inc. This work is licensed under the Creative Commons Attribution International License (CC BY 4.0).

http://creativecommons.org/licenses/by/4.0/

\begin{abstract}
This research is based on pecking order theory, which is one of the major capital structure determinant theory, driven by the information asymmetry. The purpose of this research is to investigate whether the pecking order theory provides an accurate description of companies financing choices in the context. Further, to examine whether informational asymmetry plays an important role in determining the financing hierarchy, and whether the financial deficit variable plays a key role determining the capital structure, the analysis has been conducted by utilizing a unique dataset from the Sri Lankan listed companies within multiple industrial sectors from 2011 to 2017. Empirical analysis has been done based on Panel data analysis model with regression tools suggested. The findings suggest that company's follow original pecking order hypothesis where companies' preference towards debt is higher than equity in determining their capital structure. Moreover, financing choices are contingent on informational asymmetry. Moreover, the financial deficit variable has a significant impact compared to four more conventional capital structure determinants.
\end{abstract}

\section{Keywords}

Informational Asymmetry, Pecking Order Hypothesis, Capital Structure, Sri Lankan Companies

\section{Introduction}

Design of capital structure is one of the most important decisions confronting a company in corporate finance. Over the years, many theories of capital structure emerged directing towards achieving one of the main objectives of company's management, which is to maximize the company value. Pecking order theory is 
one of the mainstream approaches among the most influential theories of capital structure. The questions of how companies finance their operations and how they mix their sources of financing have loomed large since Modigliani and Miller $(1958,1963)$ published the celebrity paper on capital structure irrelevancy. According to Harris and Raviv (1991), many economists have contributed for developing capital structure theories based on agency costs, asymmetric information, product/input market interactions and corporate control considerations, following the path that has been mapped by Modigliani and Miller. Pecking order theory was first proposed by Donaldson (1961), which was thereupon developed by Myers and Majluf (1984) by adding theoretical framework. According to Myers (1984) and Myers and Majluf (1984), the key driving factor of the Pecking order theory is information asymmetry. Heterogeneity of the distribution of information between insiders (managers) of the company and the outside investors creates information asymmetry, which steers to adverse decisions whereas it leads to a certain order of choices between sources of finance.

Diverging from the original pecking order theory assumption, several authors including Frank and Goyal (2003), Fama and French (2005) have formed contrary arguments. They argue that there is no significant pecking order in choosing external financing, and equity is not the last choice in financing, since equity is viewed as significantly better option than private debt. In addition, Frank and Goyal (2003) have raised concerns about information asymmetry as the driving force of pecking order theory whereby companies rely on retained profit, equity and then debt as the last choice for funding. Booth et al. (2001) state that there could be persistent differences across countries, indicating that specific country factors are at work. Therefore, applicability of such theories can be inconsistent. Sri Lanka is a developing country with a less developed capital market compared to developed countries (World Bank collection of development indicators). This research tries to add to the understanding of what drives the Sri Lankan company's capital structure which contributes to both literature and practitioners.

The article is organized into eight (8) sections. Section one for general background or overview of the study. Section two discusses the research problem, questions objectives and significance. Section three reviews literature while section four discusses on theoretical framework. Next section five is about empirical methodology i.e. techniques of data analysis. Section six including data, sample and descriptive statistics. Section seven is about findings and discussion. Final section allocated for conclusions.

\section{Research Problem}

Following the foundation laid by the Myers and Maljuf (1984) on the theory of pecking order under light of information asymmetry, several scholars have advocated the theory along with empirically proven results (Shyam-Sunder \& Myers, 1999; Myers, 2001; Lemmon \& Zender, 2010; Bhamaa et al., 2015). According to them, cost of financing will increase due to the magnitude of infor- 
mation asymmetry, which remains root cause for the companies to prioritize their financing sources in order of internal funds, debt and new equity as last resort. Contrary to the original theory, Jung et al. (1996); Chen (2004); Wang and Lin, (2010) are some of the scholars who advocate revised pecking order theory and empirically proven the existence of the revised theory of pecking order. The revised theory follows the order of financing from retained earnings, equity and debt at last resort (Jung et al., 1996; Chen, 2004; Wang \& Lin, 2010). Frank and Goyal (2003) and Chen et al. (2013) show that movements in the financing deficit are closely tracked by equity rather than debt. In this context, it is worthwhile to test the pecking order theory and the explanatory power of it regarding capital structure in Sri Lankan companies.

\subsection{Research Questions}

Following research questions derived in relation to the above research problem.

1) Whether the original or revised External Pecking Order Theory is the best descriptor for the capital structure of Sri Lankan companies.

2) Whether informational asymmetry plays a leading role in the hierarchy of financing in Sri Lankan companies.

3) Whether the financial deficit plays a key role in defining the capital structure of Sri Lankan companies.

\subsection{Research Objectives}

To bring fresh insights, following were research objectives.

1) To investigate the original versus revised External Pecking Order Hypothesis.

2) To investigate the original external pecking order Hypothesis under asymmetric information conditions.

3) To verify the explanatory power of the financial deficit variable in leverage of the companies in Sri Lanka.

\subsection{Significance of the Research}

The research suggests an approach as examining the revised pecking order theory based on the methodology established for the original pecking order theory as used in Shyam-Sunder and Myers, (1999); Chirinko and Singha (2000); Lemmon and Zender (2010). Further, it dispels the doubt on the robustness of the original pecking order hypothesis and informational asymmetry in determining the financing mix in Sri Lankan companies.

The research is carried out focusing on a selected sample based on 70 publicly listed companies from 2011 to 2017. Evaluation could have used a larger, comprehensive, and detailed database for more accurate conclusion. Using only quantitative methodology comprise of panel data analysis. It could be further improved by accompanying qualitative approaches together with some different methodology as well. Firm specific effects are controlled due to unobservable 
nature of the firm specific effects. However, the outcomes might sometimes have an effect on the firm specific factors. It can be further improved by considering firm specific effects.

\section{Literature Review}

\subsection{Capital Structure Theories}

Capital structure is the relative proportions of equity and debt capital used to meet the financing needs of a company and said to be high levered or low levered based on the level of the debt and equity composition. Decision of capital structure is said to be one of the most important decisions confronting a company in corporate finance (Schoubben \& van Hulle, 2004). Modigliani and Miller (1958) with a pioneering study laid the foundation for the modern theories of capital structure. Each of these approaches (low levered or high levered) consists of its own advantages and disadvantages simultaneously. Regardless of the debt equity mix that companies use to finance their operations, value of the companies is determined based on the company's earning power and by the risk of its underlying assets. This theory is known as capital structure irrelevance theory. However, the basic assumptions of this proposition, which is based on perfect capital markets with no market deficiencies and taxes, which will not be the real-world scenario always. Myers (1984) has pushed research focus on some new directions on capital structure puzzle by contrasting two ways of thinking about capital structure. One approach is the static trade-off framework which company sets a target debt-to-value ratio and gradually moves towards it. By conducting a rigorous review and synthesis of some of the earlier theoretical and empirical literature, Harris and Raviv (1991) have compiled theoretical approaches to capital structure determinants and they identified major four categories of determinants of capital structure as below.

1) Ameliorate conflicts of interest among various groups with claims to the company's resources, including managers (the agency approach).

2) Convey private information to capital markets or mitigate adverse selection effects (the asymmetric information approach).

3) Influence the nature of products or competition in the product/input market, or.

4) Affect the outcome of corporate control contests.

Among these four major approaches, this research mainly focuses on the aspect of information asymmetry approach. According to Harris and Raviv (1991), this approach assumes company's managers or insiders are assumed to possess private information about the characteristics of the company's return stream or investment opportunities. Following the information asymmetry approach, Myers and Maljuf (1984) argue that the capital structure is designed to mitigate inefficiencies in the company's investment decisions that are caused by the information asymmetry where managers of the company know more about the company and its investment opportunities than the investors do. Further, it as- 
sumes that managers who have the control over the company always act in the interest of the existing shareholders and do not issue shares, which is undervalued because issuing shares at a lower price will transfer value from existing shareholders to new investors and will give bad news to investors that the reason to issue shares is assets-in-place are overvalued. Lemmon and Zender (2010) note that small, high-growth firms can reasonably expect to have large information asymmetries with assets in place than the large, mature firms where Myers (2001) state that the price drops is higher when the information asymmetry is large.

\subsubsection{Trade-Off Theory}

The modern corporate finance literature focuses on pecking order and trade-off as two competing models in explaining financial decisions of companies regarding capital structure. Trade-off theory states that the company should consider trade-off between the tax shield benefit and the financial distress cost when determining the level of debt and equity of the company to maximize companies' value. Shyam-Sunder and Myers (1994) state that the pecking order hypothesis could be rejected if actual financing follows the static trade-off story and has tested static trade-off against pecking order models of capital structure. Further, the literature comprises of recent empirical researches on the two competing models among countries. ZéliaSerrasqueiro and Ana Caetano (2015) have tested trade-off theory versus pecking order theory in a peripheral region of Portugal where Zhang and Kanazaki (2007) has tested static trade-off against pecking order models of capital structure in Japanese companies. Shyam-Sunder and Myers (1994) state that according to trade-off theory, variation of the debt ratio is explained by deviations of the existing ratio of debt from the target ratio of debt. Contradictorily, pecking order explains that the variation of the debt ratio is due to inadequate internal cash flows of the company to cover its investments and dividend commitments. Therefore, in trade off theory, leverage ratio is driven by target capital ratio where in pecking order theory, leverage ratio is driven by the financial deficit (Shyam-Sunder \& Myers, 1994).

\subsubsection{Market Timing Theory}

A further argument for Pecking order Hypothesis comes from the market timing theory which is based on equity market timing referring issuing shares at high prices and repurchasing at low prices. Huang and Ritter (2009) argue that the companies prefer external equity when the cost of equity is low, and prefer debt otherwise where financing mix reflects the attempts to time the equity market. Companies issue equity when they perceive the relative cost of equity as low, and issue debt when they perceive the relative cost of equity as high. Hence, equity finance will dominate whenever company has opportunity to sell overpriced equity (Baker \& Wurgler, 2002). Further, Baker and Wurgler (2002) has found that the low-leverage companies tend to be the companies that have raised funds when their market to book values were high, and conversely high-leverage com- 
panies tend to be those that have raised funds when their market to book values were low. The incentive of this theory is to make use of temporary fluctuations in the cost of equity relative to the cost of other financial sources. According to Modigliani and Miller (1958), cost of financial sources does not vary exogenous. However, for rational or irrational reasons cost of finance varies across companies and over time.

\subsubsection{Pecking Order Theory}

Donaldson (1961) has initially suggested the argument of pecking order theory and Myers and Majluf (1984) have developed the theory by giving a theoretical framework. Myers (1984) states that according to pecking order theory, a company favours internal finance (retained earnings) over external finance. This leads companies to go for external financing, only if they are running out of internal funds on their investments. This hypothesis is driven by the inverse relationship of the profitability and the debt ratios. Companies with the higher profits will finance their financial deficit by means of profits (retained earnings). Booth et al. (2001) found that the more profitable companies tend to use less debt. This result does not sit with the trade-off theory where it argues companies that are more profitable could use debt to obtain high tax shield benefit. Frank and Goyal (2003) states profitable companies should be highly levered to offset corporate taxes where Rajan and Zingales (1995) have found strong negative relationships between debt ratios and past profitability. Sánchez-Vidal and MartínUgedo (2005) finds that most Spanish companies small to medium-size do follow the pecking order of finance where coefficients of retained earnings are higher than those of debt, and debt coefficients are in turn higher than equity issue coefficients of financing. Further high-growth firms than the low growth companies tend to follow pecking order of finance where the more leveraged companies also closely follow pecking order of finance. Lemmon and Zender (2010) show that the pecking order theory is a good descriptor of the financing behaviour of the companies. Bhamaa et al. (2015) have focused on companies with normal as well as large deficits and surpluses. Watson and Wilson (2002) support the pecking order in SMEs where information asymmetry is at particular intense.

\subsubsection{Information Asymmetry}

Pecking order theory postulates that the hierarchy of financing would be internal funds, debt and finally equity at last resort. Myers and Maljuf (1984) argue that the underlying reason for the existence of this hierarchy is information asymmetry. Myers (2001) shows when a company announces a share issue, it will good news or bad news for investors based on the information that they possess. It will be good news for investors if the share issue is for a growth opportunity with positive net present value. It will be bad news for who believes the assets-in-place are overvalued by investors and try to issue overvalued shares by the company. Information asymmetry is reason to be equity is a less preferred because, when equity is raised by the managers who have better knowledge about the company 
than investors do, the investors tend to believe that the company is overvalued and the managers are trying to get the advantage of the fact. Therefore, it is argued that a fair price for the stock in the market cannot be set and as a result, investors tend to decrease the value of the equity on their perspective.

\subsubsection{Revised Pecking Order Theory}

Contradictorily some other empirical evidences advocate that the revision of external pecking order hypothesis showing in the hierarchy of financing after internal funds, equity follows financial deficit closer than the debt. Chen (2004) investigated the capital structure determinants of Chinese companies and mention that capital choices decisions seem to follow a new pecking order where, after retained earnings immediately comes equity and then debt as last resort. Delcoure (2007) argues that the empirical results follow a modified Pecking order in the capital structure of companies in Central and East European countries. It further explains managers' preference of equity over debt is because equity is not obligatory; it may appear to be free source of capital. Wang and Lin (2010) suggest that there is an equilibrium whereby high-quality firms issue new equity and low-quality firms issue debt in the market. Several studies shed further light on potential for the revised External Pecking Order Theory. Jung et al. (1996) report that companies typically prefer equity rather debt regardless of whether they have valuable opportunities, since companies often depart from the pecking order because of agency considerations. Above stated order of finances are a clear-cut contradiction for original External pecking Order Theory. Fama and French (2002) find that small and high-growth companies mostly issue equity.

Frank and Goyal (2003) argues that according to the pecking order theory, financing behaviour is driven by cost of asymmetric information. Therefore, the theory should perform best among firms that face particularly severe information asymmetry problems. Small high-growth firms are often thought to be the firms with large information asymmetries. Contrary to this hypothesis, small high-growth firms do not behave according to the pecking order theory. However, the research shows pecking order theory works best in the large companies. Fama and French (2005) state that the information asymmetry problem is not the sole determinant of the capital structure arguing that without asymmetric information, pecking order could have built only on transaction cost. It further argues on equity being the last resort of finance emphasizing that equity retiring is not rare and it rejects the External Pecking order Hypothesis. Chen et al. (2013) have evaluated the applicability of Pecking order theory and market timing theory in Taiwan stock market and reported that the equity financing is heavily used than debt financing when internal cash flow is not sufficient to cover investment expenditure where net equity tracks the financing deficit much more closely than net debt does.

\subsection{Determinants of Capital Structure}

Harris and Raviv (1991) have observed certain factors, which determine the debt 
ratio of a company. It explains the effects of these determinants individually on debt ratio where fixed assets, non-debt tax shields, investment opportunities, and company size are positively correlated while volatility, advertising expenditure, the probability of bankruptcy, profitability and uniqueness of the product is assumed to have negative impact. Further, Rajan and Zingale (1995) have mapped tangibility of assets, the market-to-book ratio, company size, and profitability as the most influential capital structure determinants out of the determinants above mentioned.

Different theories of capital structure, are laying a theoretical base on how these factors might be correlated with leverage and the effects of it. In that case including such variables potentially poses a tough test for the pecking order theory. This theoretical reasoning is provided based on the underlying assumptions of each theory. Therefore, it can be contradictions in interpreting these determinants of capital structure.

\subsection{Developed Markets and Developing Market Hypothesis}

Singh and Hamid (1992) have investigated on companies of emerging economies compared to the companies of developed economies and stated that, companies in emerging economies rely more on equity rather than levered capital. Further, it had emphasis that the major reason for constrained financing decisions in developing capital markets are due to not having a wider range of financial instruments. Moreover, Wellalage and Locke (2014) state financing cost is a major constraint on accessibility to external finance in emerging markets. However, the implications of these theories can be generally applied to emerging markets as well. Booth et al. (2001) show that in general, debt ratios in developing countries seem to be affected in the same way and by the same types of variables that are significant in developed countries. However, there are systematic differences by country factors, such as GDP growth rates, inflation rates, and the development of capital markets. Moreover, it states that variables and the theories that are used in explaining capital structure of USA and European countries are relevant to developing countries despite the profound differences in institutional factors across these developing countries. Knowing these factors, helps predict the financial structure of a company better than knowing only its nationality. Therefore, it can be stated that the capital structure theories could be performed differently in emerging markets in contrast to the developed markets.

\subsection{Sri Lankan Capital Market and Capital Structure}

According to Colombage (2005), capital market in Sri Lanka has been functioning for more than a hundred years and comprehensive studies on the market have grown only with the economic reforms of recent decades. Further, it shows that the leverage in the corporate capital structure is relatively low in Sri Lanka and the reasons for underutilization of long-term debt as, absence of an established secondary market for debt instruments, lack of credit rating agencies, 
heavy reliance on banking sources and willingness of investors to pay premium for equity shares regardless of the company fundamentals under promising stock market with high earnings. Senerathne (1998) states that stock market conditions and the prevailing and anticipated interest rates have significant influence over Sri Lankan companies' financing decisions. Only 10\% of Sri Lankan corporate debt comprises of listed and unlisted debt and debt instruments, such as Corporate Debentures, Commercial Papers and Promissory Notes whereas 90\% is in the form of bank debt and many large Sri Lankan companies do not depend on the debt market (Samarakoon, 1999).

\subsection{Pecking Order Theory in Sri Lankan Context}

In Sri Lankan context, Senerathne (1998) has investigated the applicability of pecking order theory and sectorial analysis where the results show that companies follow pecking order partially. However, it states that agency, financial distress cost and tax shield benefit of interest cost are highly concerned factors in the context. Therefore, it confirms Sri Lankan companies partially follow trade-off theory. Further, Colombage (2005) found that the overall leverage in corporate capital structure of companies are low. However, it shows the trends in financing in companies confirm the Pecking-Order Hypothesis largely than predictions of Information Asymmetry and Static Trade-Off consideration. In addition, it specially shows the negative relationship between profitability and the leverage ratio. Ajanthan (2013) evident strong support to the pecking order theory by hotels and restaurant companies based on the relevant determinant of profitability variable in Sri Lanka and its demos that the profitable companies would tend to have lower debt ratios, since the high use of retained earnings rather than debt which is in accordance with the internal hypothesis of the pecking order theory concluding that the implication of pecking order theory is more relevant in Sri Lankan context. Wellalage and Locke (2014) also confirms that the low usage of leverage in Sri Lanka. The review of literature gives a mixed overview of the theoretical and empirical aspects regarding External Pecking Order Hypothesis. Therefore, this study is to revisit this debate; in particular, to investigate the original versus revised External Pecking Order Hypothesis, investigate the original External pecking order Hypothesis under asymmetric information conditions.

\section{Theoretical Framework-Original and Revised Pecking Order Hypothesis}

Following the theoretical framework laid by Myers (1984), Myers and Majluf (1984), Shyam-Sunder and Myers (1999) has empirically tested the theory based on the pecking order's prediction concerning the external financing sources to fill the financing deficit of companies who originally have defined pecking order concept as, issuance of corporate debt when there is an inadequacy of internal cash flows for its real investment and dividend commitments without issuing 
equity. Based on the cash inadequacy with regards to real investment and dividend commitment, they have derived financial deficit with

$$
\mathrm{DEF}_{t}=\left[\mathrm{DIV}_{t}+X_{t}+W_{t}+R_{t}-C_{t}\right]
$$

where $\mathrm{DEF}_{t}$-the Dividend payments, $X_{t}$-the Capital expenditures, $W_{t}$-the net increase in working capital, $R_{t}$-the current portion of long-term debt at start of period, $C_{t}$-operating cash flows. Watson and Wilson (2002) have tested how companies finance their deficit in total assets growth. It has assumed that total assets are comprised of total equity, debt and other equity. Therefore, any changes in total assets are due to change in debt, total equity or other liabilities like payables. Financial deficit is identified as the change in the total assets. In order to finance the deficit as stated, the companies required to issue or retire new equity, issue or retire new debt or adjust the other liabilities accordingly. However, it is assumed that the other liabilities for each company are to be randomly fluctuated.

\section{Empirical Methodology}

\subsection{Original Pecking Order Hypothesis}

To investigate this relationship between net debt issuance and the financial deficit variable, following model which suggested by Shyam-Sunder and Myers (1999) is used. Financial deficit is defined as the change in total assets minus change in retained earnings, which was suggested by Fama and French (2005) which has been adopted from the model suggested by Watson and Wilson (2002).

$$
\mathrm{NTD}_{i, t}=B_{o}+B_{p o} \mathrm{DEF}_{i, t}+e_{i, t}
$$

$\mathrm{NTD}_{i, t}$ is the Net Debt retired throughout the period and across the companies. It is the change in total debt among periods, $B_{o}$ is the equation constant and $B_{p o}$ is the pecking order coefficient. This value represents the relationship between the financial deficit and the net debt issuance. $\mathrm{DEF}_{i, t}$ denotes the Financial deficit of the companies throughout the period.

According to Chirinko and Singha (2000) to capture the debt capacity constraints, the model suggested is as follows:

$$
\mathrm{NTD}_{i, t}=B_{o}+B_{p o} \mathrm{DEF}_{i, t}+B_{p o, s q} \mathrm{DEF}_{\mathrm{sq}, i, t} e_{i, t} .
$$

\subsection{Revised Pecking Order Hypothesis}

In the above model, debt will be dominated in financing the deficit. However, in this revised model it is assumed that the equity will dominate the financial deficit over debt. Based on that we would expect to have a relation between net equity issuance and the financing deficit. So, to present such relationship, following model will be used as same as the above model with replacing the net debt issuance component by net equity issuance (Chen et al., 2013; Allini et al., 2017). 


$$
\mathrm{NTO}_{i, t}=B_{o}+B_{p o} \mathrm{DEF}_{i, t+e i, t}
$$

where $\mathrm{NTO}_{i, t}$ is the amount of equity retired (new equity), and also introduce a squared term to capture any constraints on funding. As in the previous model, the use of the squared deficit term to capture the funding constraints will be used, as it is to capture the capacity constraint of equity.

$$
\mathrm{NTO}_{i, t}=B_{o}+B_{p o} \mathrm{DEF}_{i, t}+B_{p o, s q} \mathrm{DEF}_{\mathrm{sq} . i, t e i, t}
$$

\subsection{Conventional Regression}

To examine whether the financial deficit is a key driver of companies leverage, it is suggested to regress the financial deficit variable, together with the most common four conventional determinants of company's capital structure, on the debt ratio. These conventional variables are company's size, tangibility, profitability and market-to-book ratio (Rajan \& Zingles, 1995; Frank \& Goyal, 2003). Thus, estimate the following model without deficit variable and with inclusion of the financial deficit variable as follows:

$$
\begin{gathered}
\mathrm{DR}_{i, t}=a_{o}+\mathrm{BLS}_{i, t}+B_{\mathrm{TA}} \mathrm{TA}_{i, t}+B_{\mathrm{PR}} \mathrm{PR}_{i, t}+B_{\mathrm{MTB}} \mathrm{MTB}_{i, t}+e_{i, t} \\
\mathrm{DR}_{i, t}=a_{o}+\mathrm{BLS}_{i, t}+B_{\mathrm{TA}} \mathrm{TA}_{i, t}+B_{\mathrm{PR}} \mathrm{PR}_{i, t}+B_{\mathrm{MTB}} \mathrm{MTB}_{i, t}+B_{\mathrm{DEF}} \mathrm{DEF}_{i, t} e_{i, t}
\end{gathered}
$$

Debt Ratio (DR) is the total debt divided by total assets, which capture the company's leverage. Size (LS): of total assets as a proxy for company's size. Tangibility (TA): net property, plant and equipment to total assets to proxy the tangibility of assets. Profitability (PR): earnings before tax to total assets to capture companies' profitability. Market-to-Book ratio (MTB): is measured by the market value of assets (market capitalization) divided by book value of assets. These proxies are consistent with the previous works (see, Rajan \& Zingales, 1995)

\subsection{Original External Packing Order Hypothesis under Informational Asymmetry}

To examine the original pecking order hypothesis in the context of the informational asymmetry, the whole sample is partitioned into two sub-groups based on the company size (total value of company assets). Assignment of the sub groups are based on average total assets value throughout the period of seven years which a proxy for the company size. The companies are divided by using the median value of the total assets as above and below median. Median is used to avoid bias arising from extreme values. Then each of the subsamples are tested using the above regression models stated in the Equations (1)-(4).

\section{Data, Sample and Descriptive Statistics}

\subsection{Data and Sample}

Due to the constraints and unavailability of information the sample is only 70 listed companies, which are listed in the main board of Colombo Stock Exchange (CSE). Therefore, it is assumed that these selected companies will represent the characteristics of all the companies, who face capital structure 
problem while finance their capital structure with a combination of external equity and debt. The sample was selected out of all companies listed in CSE and Bank Finance and Insurance sector and Investment Trust sector are excluded due to their distinctive behaviour from the other companies and companies those with default board for two or more consecutive due to unavailability of the information. The secondary data collection method is been used to gather data. Therefore, the data has been retrieved from the financial information provided in the Handbook of Listed Companies issued by the CSE and from the annual reports of the relevant companies. Income statements and balance sheets are the most important sources of gathering required data. The period of study is covering recent 7 years from 2011 to 2017 . The sample covers $23.5 \%$ of all the listed companies from 18 sectors. Table 1 below depicts about sample of this study.

This sample includes companies that contribute to the main indexes of the CSE which consists of 13 companies from S\&P Sri Lanka 20. Moreover, the market capitalization of the sample is 1489.2 billion which represents $53.3 \%$ of the total market capitalization for all listed companies in CSE (2793 billion). The sample is slightly concentrated in the Beverage Food \&Tobacco, Diversified Holdings and Manufacturing sectors with the number of companies where Beverage Food \& Tobacco and Diversified Holdings are with the market capitalization but no single industry dominates the sample.

\subsection{Descriptive Statistics}

Table 2 is presented as one dependent and two independent variables in the

Table 1. Number of companies by industrial sectors.

\begin{tabular}{cccccc}
\hline Sector & No & $\begin{array}{c}\text { Market } \\
\text { cap } \%\end{array}$ & Sector & No & $\begin{array}{c}\text { Market } \\
\text { cap } \%\end{array}$ \\
\hline Beverage Food and Tobacco & 11 & $38.13 \%$ & Motors & 3 & $0.62 \%$ \\
Chemical and Pharmaceuticals & 3 & $0.75 \%$ & Oil Palms & 1 & $1.41 \%$ \\
Construction and Engineering & 1 & $1.05 \%$ & Plantations & 3 & $0.67 \%$ \\
Diversified Holdings & 12 & $30.35 \%$ & Power and Energy & 1 & $0.90 \%$ \\
Footwear and Textiles & 1 & $0.52 \%$ & Power and Energy & 2 & $0.61 \%$ \\
Health Care & 3 & $2.70 \%$ & Services & 1 & $0.21 \%$ \\
Hotels and Travels & 7 & $4.32 \%$ & Stores and Supplies & 1 & $0.25 \%$ \\
Investment Trust & 1 & $0.27 \%$ & Telecommunications & 2 & $8.33 \%$ \\
Land and Property & 2 & $1.57 \%$ & Trading & 2 & $1.61 \%$ \\
Manufacturing & 13 & $5.74 \%$ & Total & 70 & $100.00 \%$ \\
\hline
\end{tabular}

Source: Author's construction. 
Table 2. Descriptive statistics.

\begin{tabular}{cccccccc}
\hline & N & Mean & S.D. & Min & Median & Max & Jarque-Bera \\
\hline NTL & 490 & 787,052 & $2,740,499$ & $-10,495,270$ & 114,784 & $22,172,737$ & $11,681^{* * *}$ \\
NTD & 490 & 448,405 & $1,903,354$ & $-9,353,912$ & 0.000000 & $13,170,927$ & $7074.2^{* * *}$ \\
NTSC & 490 & $182,896.4$ & $1,299,082$. & $-500,000$ & 0.00000 & $23,268,418$ & $90,928^{* * *}$ \\
NTQ & 490 & $872,017.5$ & $2,264,642$. & $-230,5364$ & $270,658.0$ & $28,345,313$ & $61,117 .^{* * *}$ \\
DEF & 490 & $1,122,868$. & $3,424,681$. & $-13,034,018$ & $217,713.7$ & $29,511,776$ & $17,820^{* * *}$ \\
DR1 & 490 & 0.1713 & 0.1689 & 0.0000 & 0.1220 & 0.7200 & $75.46^{* * *}$ \\
DR2 & 490 & 0.3574 & 0.2192 & 0.0010 & 0.3620 & 0.8700 & $16.43^{* * *}$ \\
TA & 490 & 15.850 & 1.1595 & 12.000 & 16.000 & 19.000 & $21.08^{* * *}$ \\
TAN & 490 & 0.2528 & 0.2427 & 0.0000 & 0.1850 & 0.9612 & $63.06^{* * *}$ \\
PR & 490 & 0.1530 & 0.1702 & -0.1034 & 0.1132 & 1.4023 & $5213^{* * *}$ \\
MTB & 490 & 1.8903 & 2.1955 & 0.0906 & 1.1773 & 16.626 & $3313^{* * *}$ \\
\hline
\end{tabular}

Note: NTL: net liability issued; NTD: net debt issued; NTSC: stated capital; NTQ: net equity issued; DEF: financial deficit, DR1: debt ratio; DR2: total liability over total assets; TA: company's size; TAN: tangibility; PR: profitability; MTB: market-to-book ratio. Source: Author's statistical output.

main pecking order hypothesis. Further, the data set is presented as one dependent variable and four independent variables in the conventional regression model.

The mean debt ratio $17.13 \%$ of long-term debt and $35.74 \%$ of total liability appears to be very far from developing countries where it ranging up to $51 \%$ in developing countries (Booth et al., 2001). Further, debt ratio of Chinese companies is $46 \%$ (Chen, 2004) where $56 \%$ in Poland, $51 \%$ in Slovakia, $43 \%$ in the Czech Republic, and 34\% in Russia (Delcoure, 2007). Compared with the debt ratios in developed countries, the Sri Lankan company's book-based debt ratio, displays a low amount where countries like Canada 39\%, 48\% in France, 38\% in Germany, $47 \%$ in Italy, $53 \%$ in Japan, $28 \%$ in United Kingdom and $37 \%$ in United States, book-based debt ratios appear to be high (Rajan \& Zingales, 1995). Considering the $49 \%$ in Dutch SMEs (Degryse et al., 2012) also shows that the Sri Lanka debt ratio is comparatively low.

It is worth evaluating that the high mean and max values of net debt issued compared with net equity issued. This may refer to the preference of Sri Lankan companies to rely on debt rather than issuing equity in case of a financial deficit. In turn, they may prefer to retire debt than equity in case of surpluses (negative deficits). The implication can be stated as, in Sri Lankan companies; issuance of debt is usually higher than equity issuance. The debt retirement seems to be higher than equity retirement. The reason to follow this structure of issuance of capital in financial deficits might be the involvement of informational asymmetry and transaction cost which is $1.12 \%$ up to Rs. 100 Million and $0.61 \%$ for additional amount (CSE Annual Report 2018) in issuing new equity. In addition, the high values of MTB ratio imply that there are widows of opportunities in Sri 
Lankan equity market.

Correlations between each variable that have been included in the analysis are presented in the matrix in Table 3. Deficit shows a positive correlation with net debt, net liability, net equity and net stated capital issued. Size and the tangibility show a positive correlation with debt ratio while profitability and market to book value shows a negative correlation. With the total liability over total assets ratio all the conventional variables show a positive correlation except market to book ratio.

\section{Findings and Discussion}

\subsection{Findings on Pecking Order Hypothesis}

Results examining both the original and revised External pecking order hypothesis in Equations (1)-(4) are reported in Table 4 and Table 5. Table 4 reports the original pecking order, which represents Equation (1), Equation (2) and Table 5 reports the revised pecking order hypothesis by employing Equation (3), Equation (4). Table 4 shows both net debt and net liability as dependent variables separately. Table 4 represents the above equations with both net stated capital and net equity separately. In each case it has been examined the model with and without the squared deficit term. The above-stated models were estimated by carrying out the most common static linear panel data models namely, Fixed-effects and Random effects regression respectively as reported in Table 4 and Table 5. Diagnostic tests for models' assumptions were performed. Serial correlation can be affected the output of estimation models. In addition, regression analysis is in error in case of model misspecification. Hausman (1978) test is used to choose between fixed effects model and a random effects model with

Table 3. Correlation matrix.

\begin{tabular}{cccccccccccc}
\hline & NTL & NTD & NTSC & NTQ & DEF & DR1 & DR2 & TA & TAN & PR & MTB \\
\hline NTL & 1.000 & & & & & & & & & & \\
NTD & 0.870 & 1.000 & & & & & & & & & \\
NTSC & -0.112 & -0.145 & 1.000 & & & & & & & & \\
NTQ & 0.159 & 0.076 & 0.692 & 1.000 & & & & & & & \\
DEF & 0.390 & 0.277 & 0.005 & 0.254 & 1.000 & & & & & & \\
DR1 & 0.207 & 0.302 & -0.054 & -0.068 & 0.105 & 1.000 & & & & & \\
DR2 & 0.316 & 0.289 & -0.126 & -0.125 & 0.144 & 0.695 & 1.000 & & & & \\
TA & 0.430 & 0.338 & 0.145 & 0.455 & 0.405 & 0.113 & 0.111 & 1.000 & & & \\
TAN & 0.026 & 0.007 & -0.067 & -0.054 & 0.007 & 0.056 & 0.094 & 0.007 & 1.000 & & \\
PR & -0.05 & -0.086 & -0.043 & -0.051 & -0.033 & -0.139 & 0.228 & -0.096 & 0.023 & 1.000 & \\
MTB & -0.127 & -0.148 & 0.010 & -0.079 & -0.073 & -0.305 & -0.121 & -0.156 & -0.175 & 0.573 & 1.000 \\
\hline
\end{tabular}

Notes: NTL: net liability issued; NTD: net debt issued; NTSC: stated capital; NTQ: net equity issued; DEF: financial deficit, DR1: debt ratio; DR2: total liability over total assets; TA: company's size; TAN: tangibility; PR: profitability; MTB: market-to-book ratio. Source: Author's statistical output. 
Table 4. Equation (1) and Equation (2)-Original Pecking order hypothesis.

\begin{tabular}{ccccc}
\hline Dependent Variable: & \multicolumn{2}{c}{ NDT } & \multicolumn{2}{c}{ NTL } \\
\hline & Panel EGLS & Panel EGLS & Panel Least Squares Panel Least Squares \\
\hline & -1 & -2 & -1 & -2 \\
\hline DEF & $0.401^{* * *}$ & $0.581^{* * *}$ & $0.647^{* * *}$ & $0.714^{* * *}$ \\
& $(0.019)$ & $(18.9)$ & $(27.614)$ & $(22.309)$ \\
DEF $_{\text {sq }}$ & & $(0.00)^{* * *}$ & & $(0.000)^{* *}$ \\
& & $(-7.303)$ & & $(-3.021)$ \\
No. of observatios & 490 & 490 & 490 & 490 \\
F-Test & $436.201^{* * *}$ & $265.838^{* * *}$ & $35.327^{* * *}$ & $35.633^{* * *}$ \\
$R$ square & 0.471 & 0.5219 & 0.855 & 0.858 \\
Durbin-Watson stat & 2.247 & 2.1782 & 2.546 & 2.518 \\
Hausman Test & 0.0573 & 4.6753 & $5.792^{* *}$ & $0.975^{* * *}$ \\
\hline
\end{tabular}

Notes: NTD: net debt issued, or retired; NTL: net liability issued, or retired; DEF: financial deficit; $\mathrm{DEF}_{\mathrm{sq}}$ : financial deficit squared. Hausman test is performed to choose between the Random effects and fixed effects models. Values been expressed in parentheses are robust standard errors. ${ }^{*}{ }^{* *}$ and ${ }^{* * *}$ indicate significance at $10 \%, 5 \%$, and $1 \%$ levels, respectively. Source: Author's Statistical Output.

Table 5. Equation (3) and Equation (4)-Revised pecking order hypothesis.

\begin{tabular}{ccccc}
\hline Dependent Variable: & \multicolumn{2}{c}{ NTSC } & \multicolumn{2}{c}{ NTQ } \\
\hline & Panel Least Squares & $\begin{array}{c}\text { Panel Least } \\
\text { Squares }\end{array}$ & Panel Least Squares & $\begin{array}{c}\text { Panel Least } \\
\text { Squares }\end{array}$ \\
\hline DEF & -3 & -4 & -3 & -4 \\
\hline & $0.212^{* * *}$ & $0.143^{* * *}$ & $0.352^{* * *}$ & $0.285^{* * *}$ \\
& $(9.492)$ & $(4.692)$ & $(15.113)$ & $(8.974)$ \\
DEF $_{\text {sq }}$ & & $(0.000)^{* * *}$ & & $(0.00)^{* * *}$ \\
& & $(3.308)$ & & $(3.052)$ \\
No. of observations & 490 & 490 & 490 & 490 \\
F-Test & $4.172^{* * *}$ & $4.365^{* * *}$ & $8.793^{* * *}$ & $8.972^{* * *}$ \\
$R$ square & 0.41 & 0.425 & 0.594 & 0.603 \\
Durbin-Watson stat & 2.608 & 2.566 & 2.544 & 2.515 \\
Hausman Test & $20.604^{* * *}$ & $27.711^{* * *}$ & $5.690^{* *}$ & $9.823^{* * *}$ \\
\hline
\end{tabular}

Notes: NTSC: net stated cap issued, or retired; NTQ: net equity issued, or retired; DEF: financial deficit; $\mathrm{DEF}_{\mathrm{sq}}$ : financial deficit squared. Hausman test is performed to choose between the Random effects and fixed effects models. Values been expressed in parentheses are robust standard errors. ${ }^{*},{ }^{* *}$ and ${ }^{* * *}$ indicate significance at $10 \%, 5 \%$, and $1 \%$ levels, respectively. Source: Author's Statistical Output.

relates to model specification. Further, Durbin Watson test has been employed to test the presence of serial correlation. Result in Table 4 and Table 5 shows no serious serial correlation problems with the Durbin Watson test statistic. According to the Hausman test statistic, in Table 4 and Table 5 all the analysis is done by using panel least square method except in Equation (1) net debt column 
in Table 4 which has used the panel EGLS random effect model.

Examining the original pecking order hypothesis first, the results exert a positive and significant coefficient of 0.401 in Table 4 on financial deficit given that the dependent variable is the long-term net debt issuance (change in debt). At the same time, the coefficient of financial deficit on the dependent variable of change in total liability is 0.647 , which is significant and positive. Yet, these estimated coefficient values on financial deficit are still far below the theoretical coefficient suggested by Shyam-Sunder and Myers (1999) of being equal to one in the original pecking order prediction. Further 0.581 and 0.714 are the coefficient values of financial deficit after inclusion of financial deficit square term to the above stated two dependent variables respectively. The coefficient value increases with inclusion the square of financial deficit, which in turn exerts a negative and significant coefficient, which is in line with the prediction of pecking order. The results appear to be ostensibly consistent with the original pecking order hypothesis. The coefficient of debt in the regression, which estimated without considering deficit square term is slightly the right order of magnitude but significantly less than the simple pecking order prediction which is suggested by the Shyam-Sunder and Myers (1999) being equal to one where he has shown that the U.S.A companies ranging between 0.77 and 0.85 . Sánchez-Vidal and Martín-Ugedo (2005) also held coefficients range from 0.65 to 0.94 for Spanish companies. In addition, this comparison of results confirms the debt capacity constraints in Sri Lankan companies.

In terms of model specification, the $R^{2}$ statistic of the model stands 0.471 in Table 4 for net debt variable and 0.855 for the change in liability variable. After inclusion of financial deficit variable, it stands out 0.5219 and 0.858 respectively for both variables. It implies that the Equation (2) which captures the debt capacity constraints with the deficit square term is more appropriate in evaluating Sri Lankan companies' pecking order predictions. Considering the model's simplicity, the mentioned $R^{2}$ amount postulate that the model employed is explaining pecking order very well. Further, the F-Test values regarding the all the models significant at $1 \%$ which states that the models are fitting.

Interestingly, the results stated in Table 5 exert a positive and significant coefficient of financial deficit on stated capital issued and the change in total equity. However, these coefficients possess a lesser magnitude (0.212) for stated capital and (0.352) for total equity than the corresponding value under the original pecking order prediction. Furthermore, the coefficient value decreases with inclusion of the square of financial deficit (0.143) and (0.285) respectively, which in turn exerts a positive and significant coefficient with relating to deficit square term. Contrast to original pecking order hypothesis this indicates a preference for equity even in the case of large deficits. The $R^{2}$ values range from $41 \%$ to $42.5 \%$ for change in stated capital and $59.4 \%$ to $60.3 \%$ for change in total equity, which is lower than the original pecking order hypothesis. This confirms that in Sri Lankan context, net debt issued is more related to financial deficit rather than net equity issued and change in total liabilities is more related to change in 
total equity.

\subsection{Conventional Regression}

Referring to the further analysis of conventional variables and financial deficit as determinants of leverage, the stated model for the conventional regression was estimated by carrying out random effects and fixed effects panel regression method by taking long term debt to total assets and total liabilities to total assets as dependent variables to measure the leverage.

Table 6 reports the results for Equation (4) and Equation (5) book-based debt ratios. Random-effects model was performed using Generalized Least Square (GLS) estimator. According to the Hausman specification test, that fixed-effects model is preferred over random-effects model. The implication of these results is that the fixed-effects model is the appropriate model to test the conventional variables regression. The $R^{2}$ values are ranging from $76.3 \%$ to $85.1 \%$ respectively for two debt ratios mentioned above. Inclusion of deficit variable to the conventional regression model has increased the $R$-squared value to $76.6 \%$ and $85.6 \%$ respectively. Estimated results reveal that, company size have a significant positive impact, while profitability, tangibility and market to book value has insignificant but negative coefficients.

Table 6. Equation (5) and Equation (6) —Conventional regression model.

\begin{tabular}{ccccc}
\hline Dependent Variable: & \multicolumn{2}{c}{ DR 1 } & \multicolumn{2}{c}{ DR 2 } \\
\hline & $\begin{array}{c}\text { Panel Least } \\
\text { Squares }\end{array}$ & $\begin{array}{c}\text { Panel Least } \\
\text { Squares }\end{array}$ & Panel Least Squares & $\begin{array}{c}\text { Panel Least } \\
\text { Squares }\end{array}$ \\
\hline TA & $0.0163^{* * *}$ & $0.0116^{* *}$ & $1.35 \mathrm{E}-09^{* *}$ & $5.01 \mathrm{E}-10$ \\
& $(2.948)$ & $(1.969)$ & $(2.373)$ & $(0.838)$ \\
TAN & 0.091 & 0.092 & 0.129 & 0.043 \\
& $(1.176)$ & $(1.202)$ & $(1.623)$ & $(1.689)$ \\
PR & -0.0005 & -0.0005 & -0.009 & -0.008 \\
& $(-0.995)$ & $(-0.958)$ & $(-1.587)$ & $(-1.541)$ \\
MTB & -0.0004 & -0.003 & -0.008 & -0.0007 \\
& $(-0.0800)$ & $(-0.072)$ & $(-0.154)$ & $(-0.143)$ \\
DEF & & $0.00485^{* *}$ & & $8.08 \mathrm{E}-09^{* * *}$ \\
& & $(2.263)$ & & $(4.015)$ \\
No of Obs & 490 & 490 & 490 & 490 \\
F-Test & $18.401^{* * *}$ & $18.402^{* * *}$ & $32.658^{* * *}$ & $33.606^{* * *}$ \\
$R$ square & 0.763 & 0.766 & 0.851 & 0.856 \\
Durbin-Watson stat & 1.121 & 1.126 & 1.059 & 1.092 \\
Hausman Test & $10.1461^{* *}$ & & $11.700^{* *}$ & $14.846^{* *}$ \\
\hline
\end{tabular}

Notes: DR1: debt ratio 1; DR2: debt ratio 2; TA: company's size; TAN: tangibility; PR: profitability; MT market-to-book ratio; DEF: financial deficit. Hausmen Test is performed to choose between random effects and fixed effects model. Values been expressed in parentheses are standard errors. ${ }^{*}{ }^{* *}$ and ${ }^{* * *}$ indicate significance at $10 \%, 5 \%$, and $1 \%$ levels, respectively. 


\subsection{Original Pecking Order Hypothesis under Informational Asymmetry}

Informational asymmetry is the major consideration, which is affecting financing behaviour in the Pecking order theory (Myers \& Majluf, 1984). Therefore, it is expected that the theory to perform well among companies who face higher levels of informational asymmetry. The difference between the corporate insiders and the market investors concerning information that they have is naturally expected to be high in small firms and high growth firms (Frank \& Goyal, 2003). Evidently, smaller and high growth companies are proved to have greater informational asymmetry (Chen et al., 2013; Komera \& Lukose, 2015). In estimating the model, it is particularly interested in the coefficient on the financial deficit. For the original External pecking order theory to hold, the expectation is that the magnitude of the coefficient of financial deficit with net debt to be larger for smaller companies as such companies are more likely to experience informational asymmetry.

Table 7 and Table 8 depict the results based on company's size. Results obtained for the sub samples reveal that a robust pattern whereby Sri Lankan smaller companies are being more likely to adhere to the original pecking order hypothesis rather than larger companies. That is, the coefficient on the financial deficit with debt $(0.556)$ and liability $(0.885)$ is greater for smaller companies than for larger companies, which is $(0.398)$ and (0.674). This result is thus consistent with the original pecking order predictions and the informational asymmetry model.

Table 7. Larger companies.

\begin{tabular}{|c|c|c|c|c|c|c|c|c|}
\hline \multirow[t]{2}{*}{ Dependent Variable: } & \multicolumn{2}{|c|}{ NDT } & \multicolumn{2}{|c|}{ NTL } & \multicolumn{2}{|l|}{ NTSC } & \multicolumn{2}{|c|}{ NTQ } \\
\hline & Panel EGLS & Panel EGLS & Panel EGLS & Panel EGLS & Panel Least Squares & Panel EGLS & Panel EGLS & Panel EGLS \\
\hline & 1 & 2 & 1 & 2 & 3 & 4 & 3 & 4 \\
\hline \multirow[t]{2}{*}{$\mathrm{DEF}$} & $0.398^{* * *}$ & $0.585^{\star * *}$ & $0.674^{* * *}$ & $0.736^{\star * *}$ & $0.217^{* * *}$ & $0.148^{\star * *}$ & $0.291^{* * *}$ & $0.187^{\star * *}$ \\
\hline & $(14.184)$ & (13.099) & $(24.214)$ & $(16.903)$ & $(6.789)$ & $(3.37)$ & $(7.745)$ & $(3.431)$ \\
\hline \multirow[t]{2}{*}{$\mathrm{DEF}_{\mathrm{sq}}$} & & $-00111^{\star * *}$ & & $-0.00384^{* * *}$ & & $0.00486^{* * *}$ & & $0.0692^{* * *}$ \\
\hline & & $(-5.216)$ & & $(-1.833)$ & & -2.234 & & -2.597 \\
\hline No. of observations & 245 & 245 & 245 & 245 & 245 & 245 & 245 & 245 \\
\hline F-Test & $201.977^{\star * *}$ & $124.63^{* * *}$ & $580.80^{* * *}$ & $295.395^{* * *}$ & $4.041^{\star * *}$ & $4.143^{* * *}$ & $60.22^{* * *}$ & $34.167^{* * *}$ \\
\hline$R$ square & 0.453 & 0.507 & 0.705 & 0.709 & 0.403 & 0.417 & 0.198 & 0.22 \\
\hline Durbin-Watson stat & 2.262 & 2.185 & 2.198 & 2.178 & 2.603 & 2.562 & 1.992 & 1.982 \\
\hline Hausman Test & 0.056 & 2.862 & $3.315^{\star}$ & $5.907^{\star}$ & $12.33^{* * *}$ & $15.484^{* * *}$ & 0.098 & 0.355 \\
\hline
\end{tabular}

Notes: NTD: net debt issued, or retired; NTL: net liablity issued, or retired; NTSC: net stated cap issued, or retired; NTQ: net equity issued, or retired; DEF: financial deficit; $\mathrm{DEF}_{\mathrm{sq}}$ : financial deficit squared. Hausman test is performed to choose between random and fixed effect models. Values been expressed in parentheses are robust standard errors. ${ }^{\star},{ }^{* *}$ and ${ }^{* *}$ indicate significance at $10 \%, 5 \%$, and 1\% levels, respectively. Source: Author's Statistical Output. 
Table 8. Smaller companies.

\begin{tabular}{|c|c|c|c|c|c|c|c|c|}
\hline \multirow[t]{2}{*}{ Dependent Variable: } & \multicolumn{2}{|c|}{ NDT } & \multicolumn{2}{|c|}{ NTL } & \multicolumn{2}{|c|}{ NTSC } & \multicolumn{2}{|c|}{ NTQ } \\
\hline & Panel EGLS & Panel EGLS & Panel EGLS & Panel EGLS & $\begin{array}{c}\text { Panel Least } \\
\text { Squares }\end{array}$ & $\begin{array}{c}\text { Panel Least } \\
\text { Squares }\end{array}$ & Pooled-OLS & Pooled-OLS \\
\hline & 1 & 2 & 1 & 2 & 3 & 4 & 3 & 4 \\
\hline \multirow[t]{2}{*}{ DEF } & $0.556^{* * *}$ & $0.434^{* * *}$ & $0.885^{\star * *}$ & 0.885 & 0.217 & 0.148 & 0.119 & 0.171 \\
\hline & $(13.128)$ & $(9.327)$ & $(27.431)$ & $(23.38)$ & $(6.789)$ & $(3.37)$ & $(2.356)$ & $(2.897)$ \\
\hline \multirow[t]{2}{*}{$\mathrm{DEF}_{\mathrm{sq}}$} & & $0.00152^{\star * \star}$ & & $0.0081^{\star \star \star}$ & & $4.86 \mathrm{E}-09$ & & $-6.46 \mathrm{E}-08$ \\
\hline & & $(5.06)$ & & $(0.033)$ & & $(2.234)$ & & $(1.687)$ \\
\hline No. of observatios & 245 & 245 & 245 & 245 & 245 & 245 & 245 & 245 \\
\hline F-Test & $192.171^{* * *}$ & $120.744^{* * *}$ & $774.741^{* * *}$ & $385.779^{* * *}$ & $4.041^{* * *}$ & $4.143^{* * *}$ & $5.553^{* *}$ & $4.222^{* *}$ \\
\hline$R$ square & 0.441 & 0.499 & 0.761 & 0.761 & 0.403 & 0.417 & 0.022 & 0.033 \\
\hline Durbin-Watson stat & 2.285 & 2.333 & 2.426 & 2.426 & 2.603 & 2.562 & 1.38 & 1.37 \\
\hline Hausman Test & 0.141 & 3.762 & 0.005 & 0.019 & $12.335^{* * *}$ & $15.484^{* * *}$ & & \\
\hline
\end{tabular}

Notes: NTD: net debt issued, or retired; NTL: net liablity issued, or retired; NTSC: net stated cap issued, or retired; NTQ: net equity issued, or retired; DEF: financial deficit; $\mathrm{DEF}_{\mathrm{sq}}$ : financial deficit squared. Hausman test is performed to choose between random and fixed effect models. Values been expressed in parentheses are robust standard errors. ${ }^{\star},{ }^{* *}$ and ${ }^{\star *}$ indicate significance at $10 \%, 5 \%$, and $1 \%$ levels, respectively. Source: Author's Statistical Output.

Without going into detail, the model specification tests across these two tables are similar to those reported above in the original and revised pecking order hypothesis. Namely, the random and the fixed effects are selected based on Haussman test statistic, it shows that the random effects model and fixed effects both are used in the estimations. However, for the Equation (3) and Equation (4) in the smaller companies the pooled ordinary least square method has been used since it does not possess any fixed effect based on the Lagrange Multiplier. Further, there is no evidence of serial correlation, which is measured by the Durbin Watson Test statistic. The squared deficit term is found to be economically significant for only large companies since it gives predicted outcomes for the deficit term as stated in the above original and revised pecking order hypothesis only in large companies. These findings reveal that original pecking order hypothesis fares where it supposed to perform better, in consistent with the arguments of Myers and Maljuf (1984) that informational asymmetry act as an explanatory variable in predicting the relative use of debt over equity. This is contradictory to the argument of Fama and Fench (2005) which states that in determining capital structure, informational asymmetry issue is not an important concern. However, these results are in line with the predictions of Watson and Wilson (2002) and Sánchez-Vidal and Martín-Ugedo (2005) about the original pecking order theory. Therefore, the information asymmetry issue can be considered as major concern in the capital structure decisions in Sri Lankan context. 


\section{Conclusion}

Original pecking order theory explains that the companies' preference towards financial sources in order of retained earnings, debt and equity issuances as last resort. According to the theory, the preferential order of financial sources is created due to asymmetrical information snags. Contradictory to the pecking order theory, some authors advocate a revised pecking order hypothesis, whereby companies rely on retained profit, equity and then debt as the last choice for funding. Moreover, a further challenge for original pecking order theory arises from the market timing theory and trade-off theory.

Sri Lankan companies do follow the original pecking order hypothesis and commonly prefer the debt financing over equity. The results obtained for financial deficit variable for both debt and equity postulates that, the companies will issue debt in a deficit situation than issuing equity. Findings of this study also support that the informational asymmetry acts as a crucial driver in the external pecking order behaviour in Sri Lankan context and it shows its importance in issuance decisions. These results suggest that it is not need to revise the pecking order hypothesis in explaining capital structure. Distinctly, the findings show that the financial deficit variable is linked more strongly with debt issuance rather than equity issuance. The findings reflect the view that the original pecking order hypothesis is more appropriate for countries like Sri Lanka with less developed capital markets. The results obtained from this empirical study show that the insights of pecking order theory, which is one of the mainstream theories in modern capital structure theory, is adaptable in Sri Lankan context.

According to Frank and Goyal (2003), the four variables are profitability, tangibility, market to book ratio and the company size. In the evaluation of the results obtained for the individual factors that above mentioned, company size was the only variable to mark a significant relationship with the debt ratios. As per the results, company size showed a positive relationship advocating the previous work done by Rajan and Zingales (1995) while being contradictory to the argument of Myers and Majluf (1984). Moreover, the results obtained for larger companies and smaller companies under the original and revised pecking order hypothesis shows that the smaller companies finance their financial deficit than larger companies by means of debt capital. However, in the results obtained, the inclusion of financial deficit variable to the conventional regression shows that the effects of conventional variables are fading due to significance of financial deficit variable. Therefore, it can be stated that, even though the size shows a significant positive relationship with the debt ratio, it is not a main determinant of the capital structure, which is compared to financial deficit variable in Sri Lankan context though Colombage (2005) and Samarakoon (1999) have advocated a positive relationship between the company size and the debt. Tangibility of the company reports a positive relationship, which complies with the findings of some scholars including Frank and Goyal (2003). Wellalage and Locke (2014) in explaining the reasons for having this relationship positive in Sri Lankan context states that, due to banks being the main external finance providers for Sri 
Lankan companies, significant effects on capital structure is arising from collateral requirements of banks with regards to Sri Lankan firms. Therefore, the companies with more tangible assets are benefited by the collateral requirements where it opt to go for debt. The results obtained for the profitability variable exerts a negative relationship with regards to debt ratio which is advocated by Booth et al. (2001) following the pecking order hypothesis. The market to book value, which is taken as a proxy for the growth opportunities, shows a negative relationship with debt ratios complying with the previous work done by Frank and Goyal (2003).

Inclusion of the financial deficit variable to the conventional regression of capital structure, have rendered the effects of four conventional variables. Further, it states a significant positive relationship between the financial deficit variable and the debt ratio. Therefore, it shows the validity of financial deficit variable as a determinant of the debt ratio (Shyam-Sunder \& Myers, 1999). The major factor affecting financing behaviour of a company is considered to be informational asymmetry according to the Pecking order theory (Myers \& Majluf, 1984). Therefore, the expectation is that companies will follow a strict pecking order when the information asymmetry is high and vice versa. Companies which are smaller in size are considered to possess more information asymmetry compared to larger companies (Frank \& Goyal, 2003; Chen et al., 2013; Komera \& Lukose, 2015). In evaluating the validity of above stated fact in Sri Lankan context, the findings are conforming that significance of the explanatory power of information asymmetry regarding capital structure in Sri Lankan companies is high. The findings are complying with the findings of Sánchez-Vidal and Martín-Ugedo (2005), in studying the explanatory power of information asymmetry in Spanish. Further, Watson and Wilson (2002) also have found the same results for small and medium enterprises in United Kingdom. However, the findings are contradictory to the findings of Helwege and Liang (1996) and Fama and French (2005) where they report that the informational asymmetry has no power in predicting capital structure. Therefore, it can be stated that the Sri Lankan companies follow predictions of the pecking order and the major reason for the companies to follow the pecking order, is stem from the information asymmetry concern. Ultimately, findings on the above stated three dimensions postulate that the Sri Lankan companies are more consistent with the original pecking order hypothesis by supporting the literature that argues the existence of the pecking order theory and the explanatory power of the informational asymmetry in determination of capital structure.

\section{Conflicts of Interest}

The authors declare no conflicts of interest regarding the publication of this paper.

\section{References}

Ajanthan, A. (2013). Determinants of Capital Structure: Evidence from Hotel and Restaurant Companies in Sri Lanka. International Journal of Scientific and Research Pub- 
lications, 3, 1-8.

Allini, A., Rakha, S., McMillan, D. G., \& Caldarelli, A. (2017). Pecking Order and Market Timing Theory in Emerging Markets: The Case of Egyptian Firms. Research in International Business and Finance, 44, 297-308. https://doi.org/10.1016/j.ribaf.2017.07.098

Baker, M., \& Wurgler, J. (2002). Market Timing and Capital Structure. Journal of Finance, 57, 1-32. https://doi.org/10.1111/1540-6261.00414

Bhamaa, V., Jaina, P. K., \& Yadav, S. S. (2015). Does Firms' Pecking Order Vary during Large Deficits and Surpluses? An Empirical Study on Emerging Economies. Procedia Economics and Finance, 30, 155-163. https://doi.org/10.1016/S2212-5671(15)01279-4

Booth, L., Aivazian, V., Demirguc-Kunt, A., \& Maksimovic, V. (2001). Capital Structure in Developing Countries. Journal of Finance, 56, 87-130. https://doi.org/10.1111/0022-1082.00320

Chen, D., Chen, C., Chen, J., \& Huang, Y. (2013). Panel Data Analyses of the Pecking Order Theory and the Market Timing Theory of Capital Structure in Taiwan. International Review of Economics and Finance, 27, 1-13. https://doi.org/10.1016/j.iref.2012.09.011

Chen, J. J. (2004). Determinants of Capital Structure of Chinese-Listed Companies. Journal of Business Research, 57, 1341-1351. https://doi.org/10.1016/S0148-2963(03)00070-5

Chirinko, R. S., \& Singha, A. R. (2000). Testing Static Tradeoff against Pecking Order Models of Capital Structure: A Critical Comment. Journal of Financial Economics, 58, 417-425. https://doi.org/10.1016/S0304-405X(00)00078-7

Colombage, S. R. (2005). Sectorial Analysis of Corporate Capital Structure Choice-Emerging Market Evidence from Sri Lanka. Journal of Asia Pacific Business, 6, 5-35. https://doi.org/10.1300/J098v06n03_02

Degryse, H., Goeij, P., \& Kappert, P. (2012). The Impact of Firm and Industry Characteristics on Small Firm's Capital Structure. Small Business Economics, 38, 431-447. https://doi.org/10.1007/s11187-010-9281-8

Delcoure, N. (2007). The Determinants of Capital Structure in Transitional Economies. International Review of Economics and Finance, 16, 400-415. https://doi.org/10.1016/j.iref.2005.03.005

Donaldson, G. (1961). Corporate Debt Capacity: A Study of Corporate Debt Policy and the Determination of Corporate Debt Capacity. Division of Research, Graduate School of Business Administration, Harvard University, Boston. https://www.worldcat.org/search?q=au\%3ADonaldson\%2C+Gordon\%2C\&qt=hot_aut hor

Fama, E. F., \& French, K. R. (2002). Testing Trade-Off and Pecking Order Predictions about Dividends and Debt. Review of Financial Studies, 15, 1-33. https://doi.org/10.1093/rfs/15.1.1

Fama, E. F., \& French. K. R. (2005). Financing Decisions: Who Issues Stock? Journal of Financial Economics, 76, 549-582. https://doi.org/10.1016/j.jfineco.2004.10.003

Frank, M. Z., \& Goyal, V. K. (2003). Testing the Pecking Order Theory of Capital Structure. Journal of Financial Economics, 67, 217-248. https://doi.org/10.1016/S0304-405X(02)00252-0

Harris, M., \& Raviv, A. (1991). The Theory of Capital Structure. Journal of Finance, 46, 297-355. https://doi.org/10.1111/j.1540-6261.1991.tb03753.x

Hausman, J. A. (1978). Specification Tests in Econometrics. Econometrica, 46, 1251-1271. 
https://doi.org/10.2307/1913827

Helwege, J., \& Liang, N. (1996). Is There a Pecking Order? Evidence from a Panel of IPO Firms. Journal of Financial Economics, 40, 429-458. https://doi.org/10.1016/0304-405X(95)00851-5

Huang, R., \& Ritter, J. R. (2009). Testing Theories of Capital Structure and Estimating the Speed of Adjustment. Journal of Financial and Quantitative Analysis, 44, 237-271. https://doi.org/10.1017/S0022109009090152

Jung, K., Kim, Y. C., \& Stulz, R. M. (1996). Timing, Investment Opportunities, Managerial Discretion, and the Security Issue Decision. Journal of Financial Economics, 42, 159-185. https://doi.org/10.1016/0304-405X(96)00881-1

Komera, S., \& Lukose, J. (2015). Capital Structure Choice, Information Asymmetry, and Debt Capacity: Evidence from India. Journal of Economics and Finance, 39, 807-823. https://doi.org/10.1007/s12197-014-9285-3

Lemmon, M. L., \& Zender, J. F. (2010). Debt Capacity and Tests of Capital Structure Theories. Journal of Financial and Quantitative Analysis, 45, 1161-1187. https://doi.org/10.1017/S0022109010000499

Modigliani, F., \& Miller, M. H. (1958). The Cost of Capital, Corporation Finance and the Theory of Investment. American Economic Review, 48, 261-297.

Modigliani, F., \& Miller, M. H. (1963). Corporate Income Taxes and the Cost of Capital: A Correction. American Economic Review, 53, 433-443.

Myers, S. C. (1984). The Capital Structure Puzzle. Journal of Finance, 39, 574-592. https://doi.org/10.1111/j.1540-6261.1984.tb03646.x

Myers, S. C. (2001). Capital Structure. Journal of Economic Perspectives, 15, 81-102. https://doi.org/10.1257/jep.15.2.81

Myers, S. C., \& Majluf, N. S. (1984). Corporate Financing and Investment Decisions when Firms Have Information that Investors Do Not Have. Journal of Financial Economics, 13, 187-221. https://doi.org/10.1016/0304-405X(84)90023-0

Rajan, R. G., \& Zingales, L. (1995). What Do We Know about Capital Structure? Some Evidence from International Data. Journal of Finance, 50, 1421-1460.

https://doi.org/10.1111/j.1540-6261.1995.tb05184.x

Samarakoon, L. (1999). The Ownership Structure of Sri Lankan Companies. Sri Lankan. Journal of Management, 4, 143-157.

Sánchez-Vidal, J., \& Martín-Ugedo, J. F. (2005). Financing Preferences of Spanish Firms: Evidence on the Pecking Order Theory. Review of Quantitative Finance and Accounting, 25, 341-350. https://doi.org/10.1007/s11156-005-5459-6

Schoubben, \& van Hulle, C. (2004). The Determinants of Leverage. Differences between Quoted and Non Quoted Firms. Review of Business and Economic Literature, KU Leuven, Faculty of Economics and Business. No. 4, 589-621.

Senaratne, S (1998). Pecking Order of Financing: Empirical Evidence in Sri Lankan Capital Market. Sri Lankan Journal of Management, 3, No. 1 \& 2.

Shyam-Sunder, L., \& Myers, S. C. (1999). Testing Static Trade off against Pecking Order Models of Capital Structure. Journal of Financial Economics, 51, 219-244. https://doi.org/10.1016/S0304-405X(98)00051-8

Shyam-Sunder, L., \& Myers, S. C. (1994). Testing Static Trade-Off against Pecking Order Models of Capital Structure, MIT Sloan School of Management, Cambridge. https://doi.org/10.3386/w4722

Singh, A., \& Hamid, J. (1992). Corporate Financial Structure in Developing Countries, 
Papers 1. World Bank-International Finance Corporation.

Wang, K. A., \& Lin, C. A. (2010). Pecking-Order Theory Revisited: The Role of Agency Cost. Manchester School, 78, 395-411. https://doi.org/10.1111/j.1467-9957.2010.02201.x

Watson, R., \& Wilson, N. (2002). Small and Medium Size Enterprise Financing: A Note on Some of the Empirical Implications of a Pecking Order. Journal of Business Finance Accounting, 29, 557-578. https://doi.org/10.1111/1468-5957.00443

Wellalage, N. H., \& Locke, S. (2014). The Capital Structure of Sri Lankan Companies: A Quantile Regression Analysis. Journal of Asia-Pacific Business, 15, 211-230. https://doi.org/10.1080/10599231.2014.934627

Zhang, R., \& Kanazaki, Y. (2007). Testing Static Trade-off against Pecking Order Models of Capital Structure in Japanese Firms. International Journal of Accounting \& Information Management, 15, 24-36. https://doi.org/10.1108/18347640710837335 